\title{
The Use of the Polymerase Chain Reaction and Restriction Fragment Length Polymorphism Technique Associated with the Classical Morphology for Characterization of Lymnaea columella, L. viatrix, and L. diaphana (Mollusca: Lymnaeidae)
}

\author{
O mar S Carvalho/ ${ }^{+}$, Paula CM Cardoso, Pollanah M Lira, Alejandra Rumi*, \\ Andrea Roche*, Elizabeth Berne**, Gertrud Müller**, Roberta L Caldeira
}

\begin{abstract}
Laboratório de Helmintoses Intestinais, Centro de Pesquisas René Rachou-Fiocruz, Av. Augusto de Lima 1715, 30190-002
Belo Horizonte, MG, Brasil *División Zoología Invertebrados Museo de La Plata, Facultad de Ciencias Naturales y Museo,

Universidad Nacional de La Plata, Argentina **Departamento de Microbiologia e Parasitologia, Instituto de Biologia, Universidade Federal de Pelotas, Pelotas, RS, Brasil
\end{abstract}

The specific identification of Lymnaeid snails is based on a comparison of morphological characters of the shell, radula, renal and reproductive organs. However, the identification is complicated by dissection process, intra and interspecific similarity and variability of morphological characters. In the present study, polymerase chain reaction and restriction fragment length polymorphism (PCR-RFLP) techniques targeted to the first and second internal transcribed spacers (ITS1 and ITS2) rDNA and to the mitochondrial 16S ribosomal gene (16S rDNAmt) were used to differentiate the species Lymnaea columella, L. viatrix, and $\mathrm{L}$. diaphana from some localities of Brazil, Argentina, and Uruguay as well as to verify whether the molecular results corroborates the classical morphological method. PCR-RFLP analysis of the ITS1, ITS2, and $16 S$ using 12 restriction enzymes revealed characteristic patterns for $\mathrm{L}$. columella and $\mathrm{L}$. diaphana which were concordant with the classical morphology. On the other hand, for $\mathrm{L}$. viatrix populations a number of 1 to 6 profiles were generated while morphology provided the species pattern results.

Key words: Lymnaea columella - Lymnaea viatrix - Lymnaea diaphana - polymerase chain reaction and restriction fragment length polymorphism - first and second internal transcribed spacers of the RNA ribosomal gene - subunit 16S of mitochondrial RNA ribosomal gene

The genus Lymnaea Lamarck, 1799 (Basommatophora, Lymnaeidae) includes some freshwater snails that act as intermediate hosts of the liver-fluke Fasciola hepatica Linnaeus, 1758, a digenean that causes fascioliasis in animals and humans (Malek 1985, Hopkins 1992, Müller et al. 1998, Esteban et al. 1998).

Paraense (1976, 1982a,b, 1983, 1984, 1995), using the classical morphology, has reported for the South American region the following species: L. viatrix Orbigny, 1835, L. columella Say, 1817, L. diaphana King, 1830, L. cousini Jousseaume, 1887, L. rupestris Paraense, 1982b and L. plicata Scott, 1953. However, only L. viatrix, L. columella and $L$. diaphana have been found with natural infection by F. hepatica (Malek 1985).

The specific identification of these Lymnaeid snails is based on comparison of morphological characters of the shell, radula, renal and reproductive organs (Hubendick 1951, Paraense 1976, 1982a,b, 1983, 1984, 1995). The correct identification of these molluscs is important for the

Financial partial support: Fapemig, Pibic/Fiocruz, Agency of Scientifique Promotion, Argentina (BID 1201/ OC-AR PICT 01-03453)

${ }^{+}$Corresponding author. Fax: +55-31-3295.3115. E-mail: omar@cpqrr.fiocruz.br

Received 18 May 2004

Accepted 28 July 2004 detection of populations in endemic areas. However, such identification is complicated by dissection processes, intra and interspecific similarity and variability of morphological characters (Hubendick 1951, Ueta 1977, Paraense 1982a, 1983, Samadi et al. 2000). Indeed, Paraense (1994) named L. peregrina Clessin, 1882 as a synonym of $L$. columella. Ueno et al. (1975) and Paraense (1982a) have reported for the Northern Bolivian Altiplano region the species L. viatrix and L. cubensis Peiffer, 1839. Oviedo et al. (1995), however, suggested that these two species correspond to two extreme morphs of the European species $L$. truncatula; data confirmed by isoenzymatic (JabbourZahab et al. 1997) and molecular based studies (Bargues et al. 1997, Bargues \& Mas-Coma 1997).

Due to those difficulties involving the snail species identification, molecular-based tools have been used in order to support parasitological research with a wide range of applicability. One of techniques used for such purpose is polymerase chain reaction-restriction fragmente length polymorphism (PCR-RFLP), which is based on the amplification of any DNA region for the subsequent step of digestion with restriction enzymes. Thus, by using primers that anchor conserved regions there will be amplification of a target region under study.

By using PCR-RFLP targeted to the first and second internal transcribed spacers (ITS1and ITS2) regions (nuclear DNA) and to the partial subunit 16S rDNA gene (mitochondrial DNA) the present study is aimed at differentiating the species $L$. viatrix, L. columella, and $L$. 
diaphana, obtained from some localities of South America, as well as verifying whether such results corroborate the classical morphological identification.

\section{MATERIALS AND METHODS}

Snail populations - Localities and numbers of specimens of each species used are shown in the Table. All the molluscs were obtained from the field, except for $L$. viatrix specimens from Rio Grande do Sul, which were obtained from the Laboratório de Helmintologia, Universidade Federal de Pelotas (Rio Grande do Sul, Brazil). The snails were identified by means of comparative morphology based on the shell, radula, renal region, and reproductive organs accordingly to Hubendick (1951) and Paraense (1976, 1982a b, 1983, 1984, 1995). A reference snail for each DNA isolate has been preserved at the malacological collection of the Laboratório de Helmintoses Intestinais, Centro de Pesquisas René Rachou-Fiocruz.

TABLE

Origin and number of samples of the Lymnaea species used in the study

\begin{tabular}{lcl}
\hline $\begin{array}{l}\text { Species of } \\
\text { Lymnaea }\end{array}$ & $\begin{array}{c}\text { Number of } \\
\text { samples }\end{array}$ & Locality \\
\hline L. columella & 5 & Acre (Brazil) \\
& 5 & Jaboticatubas/MG (Brazil) \\
L. viatrix & 5 & Santa Catarina (Brazil) \\
& 3 & Rio Grande do Sul (Brazil) ${ }^{a}$ \\
& 3 & Buenos Aires (Argentina) $^{\text {Uruguay }}$ \\
& 3 & Chubut (Argentina) \\
& 4 & Rio Acima/MG (Brazil) \\
L. diaphana & 4 & Belo Horizonte/MG (Brazil) \\
\hline
\end{tabular}

$a$ : laboratory populations

DNA extraction - Total DNA was extracted from the feet of snails using the phenol/chloroform method as described in Vidigal et al. (1994).

rDNA-ITSI amplification - The ITS1 region was amplified using the primers ETTS2 (5'-TAACAAGG TTTCCGTAGGTGAA-3') (Kane \& Rollinson 1994) and ITS1r (5'ACGAGCGAGTGATCCACCGC 3') (Vidigal et al. 2004), anchored, respectively, in the conserved ends of $18 \mathrm{~S}$ and 5.8S ribosomal genes. PCR amplification was undertaken in a final volume of $10 \mu \mathrm{l}$ consisting of: $1-10 \mathrm{ng}$ of DNA, buffer $(1.5 \mathrm{mM} \mathrm{MgCl} 2,50 \mathrm{mM} \mathrm{KCl}, 10 \mathrm{mM}$ Tris- $\mathrm{HCl}$, $\mathrm{pH}$ 8.5), $200 \mu \mathrm{M}$ each dNTP, $0.5 \mathrm{U}$ of Taq DNA polymerase, $5.0 \mathrm{pmol}$ of each primer. PCR reactions were performed according to Vidigal et al. (2000a) except for the annealing temperature that was set to $60^{\circ} \mathrm{C}$.

rDNA-ITS2 amplification - The ITS2 region was amplified using the primers ITS2f (5' CGTCCGTCTGA GGGTCGGTTTGC 3') (Vidigal et al. 2000b) and e ETTS1 (5' TGCTTAAGTTCAGCGGGT 3') (Kane \& Rollinson 1994), anchored, respectively, in the conserved ends of $5.8 \mathrm{~S}$ and $28 \mathrm{~S}$ ribosomal genes. PCR amplification was undertaken in a final volume of $10 \mu \mathrm{l}$ consisting of: $1-10 \mathrm{ng}$ of DNA, buffer $(1.5 \mathrm{mM} \mathrm{MgCl} 2,50 \mathrm{mM} \mathrm{KCl}, 10 \mathrm{mM}$ Tris- $\mathrm{HCl}$,
$\mathrm{pH}$ 8.5), $200 \mu \mathrm{M}$ each dNTP, $0.5 \mathrm{U}$ of Taq DNA polymerase, $1.0 \mathrm{pmol}$ of each primer. PCR reactions were performed according to Vidigal et al. (2000a) except for the annealing temperature that was set to $60^{\circ} \mathrm{C}$.

16S rDNAmt amplification - The 16S region was amplified using the primers 5'CGCCTGTTTATCAAA AACAT 3' and 5'CCGGTCTGAACTCAGATCACGT 3', described by Palumbi (1996). The PCR amplification was undertaken in a volume of $10 \mu \mathrm{l}$ consisting of: 1-10 ng of DNA, buffer $(1.5 \mu \mathrm{M} \mathrm{MgCl} 2,50 \mathrm{mM} \mathrm{KCl}, 10 \mathrm{mM}$ Tris- $\mathrm{HCl}$, $\mathrm{pH}$ 8.5), $200 \mathrm{mM}$ each dNTP, $0.5 \mathrm{U}$ of Taq DNA polymerase, $1.0 \mathrm{pmol}$ of each primer. PCR reactions were performed according to Remigio and Blair (1997a).

A negative control (no template DNA) was included in all experiments. Three microliters of the amplification products were visualized on $6 \%$ silver stained polyacrylamide gels.

RFLP analysis - To evaluate possible enzymes that might yield informative RFLP profiles, five restriction enzymes (AluI, MspI, HpaII, RsaI and DdeI) for the ITS1 region, five enzymes (HaeIII, HhaI, HpaII, MboII and MnlI) for the ITS2 region and 10 enzymes (AluI, AvaI, DdeI, $H a e \mathrm{III}, H p a \mathrm{I}, H p a \mathrm{II}, M b o \mathrm{I}, M n l \mathrm{I}, M v a \mathrm{I}$ and RsaI) for the $16 \mathrm{~S}$ region were randomly chosen. The digestion was performed according to Vidigal et al. (2000a). The results were recorded with the digital camera Mavica (Sony).

\section{RESULTS}

Morphological identification of snail populations After a comparison of the morphological characters, the molluscs from Acre (Brazil), Jaboticatubas (Minas Gerais, Brazil), and Santa Catarina (Brazil) were identified as being $L$. columella. The populations from Rio Grande do Sul (Brazil), Belo Horizonte (Minas Gerais, Brazil), Rio Acima (Minas Gerais, Brazil), Uruguay, Chubut (Argentina) and Buenos Aires (Argentina) were identified as L. viatrix. The population from Santa Cruz (Argentina) was identified as $L$. diaphana.

RFLP analysis - PCR amplification of the ITS1 region generated a fragment of approximately $600 \mathrm{bp}$ for all species under study (data not shown). This region presented restriction sites for all the enzymes and revealed characteristic specific patterns for $L$. columella and L. diaphana. However, the populations identified as $L$. viatrix were not grouped by none of the restrictions enzymes that generate polymorphic profiles: one for Rio Acima (Minas Gerais, Brazil) population, one for the populations from Rio Grande do Sul (Brazil) and Buenos Aires (Argentina), one for the populations from Uruguay and Chubut (Argentina) and another for the population from Belo Horizonte (Minas Gerais, Brazil). After enzyme digestion all samples exhibited reproducible profiles and only some specimens of each species are shown here. Fig. 1 shows the profile generated by the DdeI enzyme, exhibiting the most accurate profile for differentiating those species.

PCR amplification of the ITS2 region generated fragments ranging from approximately $500 \mathrm{bp}$ (L. columela and $L$. viatrix) to $550 \mathrm{pb}$ (L. diaphana) (data not shown). Except for HhaI, all the restriction enzymes tested cut the fragments. Results from ITS2 region showed to be similar to those from ITS1, allowing differentiation between $L$. 
columella and L. diaphana. On the other hand, populations of L. viatrix showed distinct profiles for each population under study. HpaII enzyme exhibited the most accurate profile for differentiating these species (Fig. 2).

DNA amplification of the $16 \mathrm{~S}$ region generated fragments of approximately $460 \mathrm{bp}$ for $L$. columella, $520 \mathrm{bp}$ for L. viatrix, and $580 \mathrm{bp}$ for L. diaphana (data not shown). Out of the ten restriction enzymes used, only RsaI, DdeI and $M n l I$ showed restriction sites for all the populations.
Out of these, only the enzyme DdeI (Fig. 3) produced invariant species-specific profiles, which allowed us to separate the species $L$. columella, L. viatrix, and $L$. diaphana. The RsaI enzyme has also differentiated $L$. columella and L. diaphana; and for the L. viatrix populations, only that from Rio Acima showed distinct profiles (data not shown). The enzyme $M n l$ I produced similar results compared to the others used for ITS1 region (data not shown).

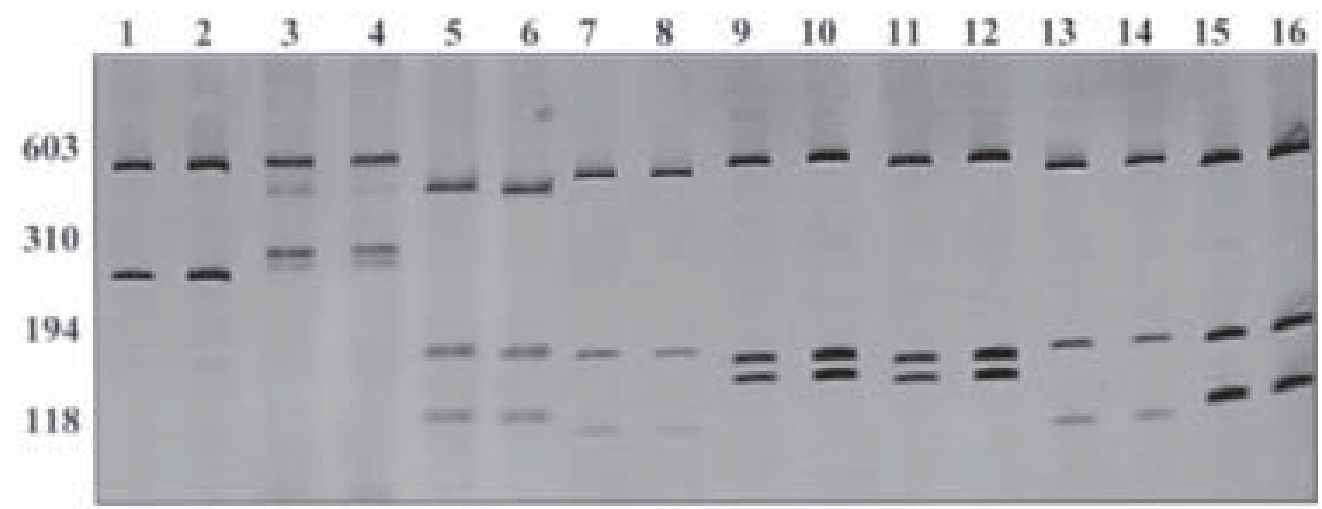

Fig. 1: silver-stained $6 \%$ polyacrylamide gel showing restriction fragment length polymorphism profiles obtained after digestion of the rDNA first internal transcribed spacer with DdeI enzyme. Lanes - 1: Lymnaea columella from Acre, Brazil (BR); 2: L. columella from Jaboticatubas, Minas Gerais, BR; 3, 4: L. diaphana from Santa Cruz, Argentina (AR); 5, 6: L. viatrix from Rio Acima, Minas Gerais, BR; 7, 8: L. viatrix from Rio Grande do Sul, BR; 9, 10: L. viatrix from Uruguay; 11, 12: L. viatrix from Chubut, AR; 13, 14: L. viatrix from Buenos Aires, AR; 15, 16: L. viatrix from Belo Horizonte, Minas Gerais, BR. Molecular size markers are shown on the left side of the figure. The molecular marker used was $\varnothing$ x 174 .

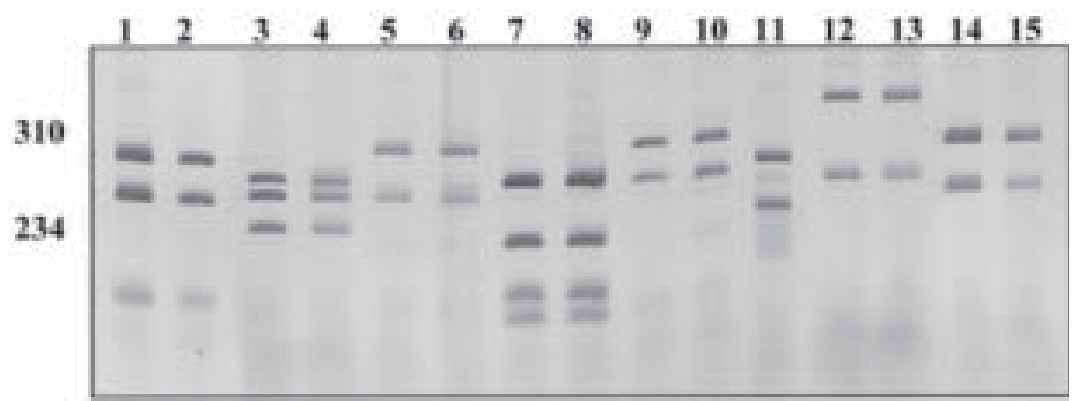

Fig. 2: silver-stained $6 \%$ polyacrylamide gel showing restriction fragment length polymorphism profiles obtained after digestion of the rDNA second internal transcibed spacer with HpaII enzyme. Lanes - 1: Lymnaea columella from Acre, Brazil (BR); 2: L. columella from Jaboticatubas, Minas Gerais, BR; 3, 4: L. diaphana from Santa Cruz, Argentina (AR); 5, 6: L. viatrix from Rio Grande do Sul, BR; 7, 8: $L$. viatrix from Buenos Aires, AR; 9, 10: L. viatrix from Uruguay; 11: L. viatrix from Chubut, AR; 12, 13: L. viatrix from Belo Horizonte, Minas Gerais, BR; 14, 15: L. viatrix from Rio Acima, Minas Gerais, BR. Molecular size markers are shown on the left side of the figure. The molecular marker used was $\varnothing \times 174$.

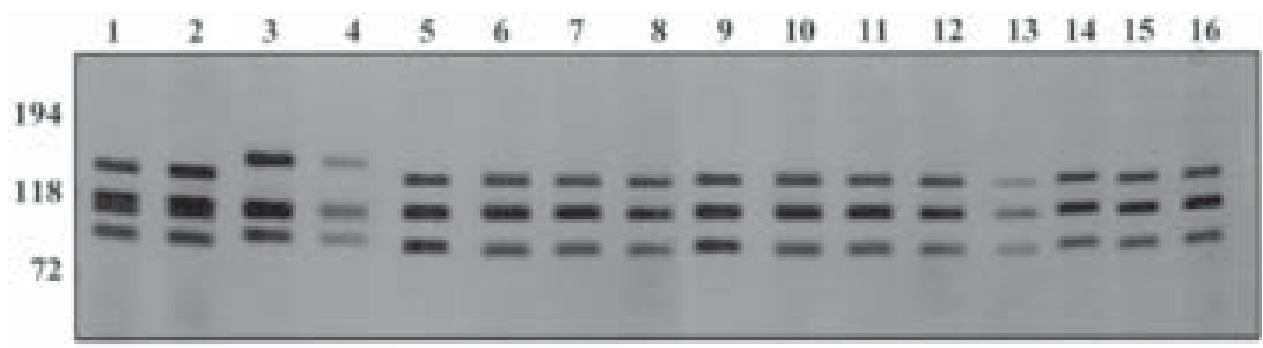

Fig. 3: silver-stained 6\% polyacrylamide gel showing the restriction fragment length polymorphism profiles obtained by digesting of the partial subunit 16S rDNA mitochondrial using the DdeI enzyme. Lanes - 1: Lymnaea columella from Acre, Brazil (BR); 2: L. columella from Jaboticatubas, Minas Gerais, BR; 3, 4: L. diaphana from Santa Cruz, Argentina (AR); 5, 6: L. viatrix from Rio Acima, Minas Gerais, BR; 7, 8: L. viatrix from Rio Grande do Sul, BR; 9, 10: L. viatrix from Uruguay; 11, 12: L. viatrix from Chubut, AR; 13, 14: L. viatrix from Buenos Aires, AR; 15, 16: L. viatrix from Minas Gerais, Belo Horizonte, BR. Molecular size markers are shown on the left side of the figure. The molecular marker used was $\varnothing$ x 174 . 


\section{DISCUSSION}

In the present study, we used the PCR-RFLP technique targeted to different DNA regions (ITS, ITS2, 16S) and compared the molecular results obtained with the traditional morphology identification. Because there is a paucity of information about the taxonomy of the Lymnaeid group, especially those from South America, we decided to use molecular markers of different evolution rate in order to obtain more reliable molecular results. Indeed, Anderson (2001) has shown how molecular data from a single genetic marker can lead to ambiguous conclusions, emphasizing the importance of utilizing more than one marker in studies on parasite species.

From analyses of ITS1 and ITS2 region, we have observed that all the enzymes used for both regions produced profiles for L. columella and L. diaphana that were identical among the species and distinguishable from the others. Our molecular results are in accordance with the classical morphological identification. Nevertheless, those regions exhibited a high level of polymorphism for $L$. viatrix populations. By using the $16 \mathrm{~S}$ region of rDNAmt, only $D d e$ I, out of the ten restriction enzymes under study, was able to cluster all $L$. viatrix populations. Such polymorphism may be mirroring an intra-specific variation as already remarked on other organisms by using the same rDNA regions (Hope \& McManus 1994, Stothard \& Rollinson 1997, Bargues et al. 2001).

However, morphological and anatomical studies on $L$. viatrix carried out by Paraense (1976) and Hubendick (1951) have raised the issue whether all the specimens included in the same taxa really belong to that species. Moreover, Durand et al. (2002) analyzed the genetic variability of three $L$. viatrix populations (from Lima/Peru, Tacna/Peru, and Bahia Blanca/Argentina) based on isoenzymatic studies and observed the occurrence of several distinct genetic entities in those samples, suggesting that the South American taxa include at least three taxonomic units.

The PCR-RFLP technique has been successfully used for specific identification of several organisms. This molecular biology methodology is simple, robust, and rapid and has proved to be an important additional tool in studies on morphological identification of molluscs (Vidigal et al. 2000a, Caldeira et al. 2000, Carvalho et al. 2001, Stothard et al. 2001); arthropods (Clark et al. 2001); helminthes (Mayta et al. 2000, Caldeira et al. 2003) and protozoan (Kong et al. 2002). Recently, sequence analyses of the large subunit (16S) of the mitochondrial ribosomal DNA have provided a distinction among several Lymnaeid species and data for phylogenetic relationships studies (Remigio \& Blair 1997a, Remigio 2002). Remigio and Blair (1997b), using the ITS1 and ITS2 of the nuclear ribosomal DNA for the three members of the subgenus Stagnicola s. str, demonstrated that they were similar and such data could be taken as evidence that the snails are conspecific or are sister species. Furthermore, these authors have shown the most useful markers to differentiate two very closely related subgenera (Stagnicola and Hinkleyia). Bargues et al. (2001) sequenced the ITS2 region from 66 populations of 13 European species and one North Ameri- can species and obtained phylogenetic trees which could resolve supraspecific, specific and population Lymnaeid relationships, distinguishing many genotypes in a total of 11 species (including two sub-species) distributed in four different genera (one comprising two subgenera). Klossa-Kilia et al. (2002), using PCR-RFLP technique directed to $16 \mathrm{~S}$ rDNAmt, obtained species specific restriction patterns that enabled clear discrimination among five fish roe Mugilidae species.

The results showed here suggest that further morphological and phylogenetic studies on $L$. viatrix are necessary, in order to better understand the actual taxonomical status of that species and association with other populations. On the other hand, results provided for the species $L$. columella and $L$. diaphana by using PCR-RFLP are in agreement with classical taxonomy, emphasizing the usefulness of such molecular technique for molluscs differentiation.

\section{REFERENCES}

Anderson TJC 2001. The dangers of using single locus markers in parasite epidemiology: Ascaris as a case study. Trends Parasitol 17: 183-188.

Bargues MD, Mas-Coma S 1997. Phylogenetic analysis of lymnaeid snails based on $18 \mathrm{~S}$ rDNA sequences. Mol Biol Evol 14: 569-577.

Bargues MD, Mangold AJ, Muños-Antoli C, Pointier JP, Mas-Coma 1997. SSU rDNA characterization of lymnaeid snails transmitting human fascioliasis in South and Central America. J Parasitol 83: 1086-1092.

Bargues MD, Vigo M, Horak P, Dvorak J, Patzner RA, Pointier JP, Jackiewicz M, Meier-Brook C, Mas-Coma S 2001. European Lymnaeidae (Mollusca: Gastropoda), intermediate hosts of trematodiases, based on nuclear ribosomal DNA ITS-2 sequences. Infec Gen Evol 1: 85-107.

Caldeira RL, Carvalho OS, Mendonça CLFG, Graeff-Teixeira C, Silva MCF, Ben R, Maurer R, Lima WS, Lenzi HL 2003. Molecular differentiation of Angiostrongylus costaricensis, A. cantonensis, and A. vasorum by polymerase chain reaction and restriction fragment length polymorphism. Mem Inst Oswaldo Cruz 98: 1039-1043.

Caldeira RL, Vidigal THDA, Matinela L, Simpson AJG, Carvalho OS 2000. Study of planorbids from Venezuela by polymerase chain reaction amplification and restriction fragment length polymorphism. Mem Inst Oswaldo Cruz 95: 171177.

Carvalho OS, Caldeira RL, Simpson AJG, Vidigal THDA 2001. Genetic variability and molecular identification of Brazilian Biomphalaria species (Mollusca: Planorbidae). Parasitology 123: S197-S209.

Clark TL, Meinke LJ, Foster JE 2001. PCR-RFLP of the mitochondrial cytochrome oxidase (subunit 1) gene provides diagnostic markers for selected Diabrotica species (Coleoptera: Chrysomelidae). Bull Entomol Res 91: 419-427.

Durand P, Pontier JP, Escoubeyrou K, Arenas JA, Yong M, Amarista M, Bargues MD, Mas-Coma S, Renaud F 2002. Occurrence of a sibling species complex within Neotropical lymnaeids, snail intermediate hosts of fascioliasis. Acta Trop 83: 233-240.

Esteban JG, Bargues MD, Mas-Coma S 1998. Geographical distribution, diagnosis and treatment of human fascioliasis: a review. Res Rev Parasitol 58: 13-48.

Hopkins DR 1992. Homing in on helminths. Am J Trop Med Hyg 46: 626-634.

Hope M, McManus DP 1994. Genetic variation in geographi- 
cally isolated populations and subspecies of Oncomelania hupensis determined by a PCR-based RFLP method. Acta Trop 57: 75-82.

Hubendick B 1951. Recent Lymnaeidae. Their variation, morphology, nomenclature and distribution. K. Sven. Vetenskapsakad. Fjärde Serien 3: 1-223.

Jabbour-Zahab R, Pointier JP, Jourdane J, Jarne P, Oviedo JA, Bargues MD, Mas-Coma S, Angles R, Perera G, Balzan C, Khallaayoune K, Renaud F 1997. Phylogeography and genetic divergence of some lymnaeid snails, intermediate hosts of human and animal fascioliasis, with special reference to lymnaeids from the Bolivian Altiplano. Acta Trop 64: 191-203.

Kane RA, Rollinson D 1994. Repetitive sequences in the ribosomal DNA internal transcribed spacer of Schistosoma haematobium, Schistosoma intercalatum and Schistosoma mattheii. Mol Bioch Parasitol 63: 153-156.

Klossa-Kilia E, Papasotiropoulos V, Kilias G, Alahiotis S 2002. Authentication of Messolongi (Greece) fish roe using PCRRFLP analysis of 16s rRNA mtDNA segment. Food Cont 13: $169-172$.

Kong HH, Shin JY, Yu HS, Kim J, Hahn TW, Hahn YH, Chung DI 2002. Mitochondrial DNA restriction fragment length polymorphism (RFLP) and $18 \mathrm{~S}$ small-subunit ribosomal DNA PCR-RFLP analyses of Acanthamoeba isolated from contact lens storage cases of residents in Southwestern Korea. J Clin Microbiol 40: 1199-1206.

Malek EA 1985. Snails hosts of schistosomiasis and other snailtransmitted diseases. In Tropical America: A Manual, PAHO Scientific Publication 478, 325 pp.

Mayta H, Talley A, Gilman RH, Jimenez J, Verastegui M, Ruiz M, Garcia HH, Gonzalez AE 2000. Differentiating Taenia solium and Taenia saginata infections by simple hematoxylin-eosin staining and PCR-restriction enzyme analysis. $J$ Clin Microbiol 38: 133-137.

Müller G, Lara SIM, Silveira Jr P, Antunes PL 1998. Acompanhamento laboratorial do ciclo biológico de Lymnaea viatrix, hospedeiro intermediário de Fasciola hepatica. Rev Bras Agric 4: 172-176.

Oviedo JA, Bargues MD, Mas-Coma S 1995. Lymnaeid snails in the human fascioliasis high endemic zone of the Northern Bolivia Altiplano. Res Rev Parasitol 55: 35-43.

Palumbi SR 1996. Nucleic acids II: the polymerase chain reaction. In DM Hillis, C Moritz, BK Mable (eds), Molecular Systematics, Sinauer, Sunderland, MAS, p. 205-548.

Paraense WL 1976. Lymnaea viatrix: a study of topotypic specimens (Mollusca, Lymnaeidae). Rev Brasil Biol 36: 419428.

Paraense WL 1982a. Lymnaea viatrix and Lymnaea columella in the Neotropical Region: a distributional outline. Mem Inst Oswaldo Cruz 77: 181-188.

Paraense WL 1982b. Lymnaea rupestris sp.n. from Southern Brazil (Pulmonata: Lymnaeidae). Mem Inst Oswaldo Cruz 77: 437-443.

Paraense WL 1983. Lymnaea columella in Northern Brazil. Mem Inst Oswaldo Cruz 78: 477-482.

Paraense WL 1984. Lymnaea diaphana: a study of topotypic specimens (Pulmonata: Lymnaeidae). Mem Inst Oswaldo Cruz 79: 75-81.

Paraense WL 1994. Lymnaea peregrina Clessin, 1882, synonym of Lymnaea columella Say, 1817 (Gastropoda: Lymnaeidae). Mem Inst Oswaldo Cruz 89: 561-566.

Paraense WL 1995. Lymnaea cousini Jousseaume, 1887, from Ecuador (Gastropoda: Lymnaeidae). Mem Inst Oswaldo Cruz 90: 605-609.

Remigio EA 2002. Molecular phylogenetic relationships in the aquatic snail genus Lymnaea, the intermediate host of the causative agent of fascioliasis: insights from broader taxon sampling. Parasitol Res 88: 687-696.

Remigio EA, Blair D 1997a. Molecular systematics of the freshwater snail family Lymnaeidae (Pulmonata: Basommatophora) utilizing mitochondrial ribosomal DNA sequences. J Moll Stud 63: 173-185.

Remigio EA, Blair D 1997b. Relationships among problematic North American stagnicoline snails (Pulmonata: Lymnaeidae) reinvestigated using nuclear ribosomal DNA internal transcribed spacer sequences. Can J Zool 75: 1540-1545.

Samadi S, Roumégoux A, Bargues MD, Mas-Coma S, Yong M, Pontier JP 2000. Morphological studies of lymnaeid snails from human fascioliasis endemic zone of Bolivia. J Mollus Stud 66: 31-44.

Stothard R, Rollinson D 1997. Molecular characterization of Bulinus globosus and B. nasutus on Zanzibar, and na investigation of their roles in the epidemiology of Schistosoma haematobium. Trans R Soc Trop Med Hyg 91: 353-357.

Stothard JR, Brémond P, Andreamaro L, Sellin B, Sellin E, Rollinson D 2001. Bulinus species on Madagascar: molecular evolution, genetic markers and compatibility with Schistosoma haematobium. Parasitology 123: S261-S275.

Ueno H, Arandia R, Morales G, Medina 1975. Fascioliasis livestock and snail host for Fasciola in the Altiplano region of Boliva. Natl Inst Anim Health 15: 61-67.

Ueta M 1977. Variações anatômicas em Lymnaea columella (Mollusca, Gastropoda). Rev Soc Brasil Med Trop 11: 217237.

Vidigal THDA, Caldeira RL, Simpsom AJG, Carvalho OS 2000a. Further studies on the molecular systematics of Biomphalaria snails from Brazil. Mem Inst Oswaldo Cruz 95: 57-66.

Vidigal THDA, Dias Neto E, Carvalho OS, Simpson AJG 1994. Biomphalaria glabrata: extensive genetic variation in Brazilian isolates by random amplified polymorphic DNA analysis. Exp Parasitol 79: 187-194.

Vidigal THDA, Kissinger JC, Caldeira RL, Pires EC, Monteiro E, Simpson, AJ, Carvalho OS 2000b. Phylogenetic relationships among Brazilian Biomphalaria species (Mollusca: Planorbidae) based upon analysis of ribosomal ITS2 sequences. Parasitology 121: 611-620.

Vidigal THDA, Spatz L, Kissinger J K, Redondo RAF, Pires ECR, Simpson AJ, Carvalho OS 2004. Analysis of the first and second internal transcribed spacer sequences of the ribosomal DNA in Biomphalaria tenagophila complex (Mollusca:Planorbidae). Mem Inst Oswaldo Cruz 99: 153158 . 
